\title{
Myeloid-derived suppressor cells in multiple myeloma: pre-clinical research and translational opportunities
}

\author{
Cirino Botta ${ }^{1}$, Annamaria Gullà ${ }^{1}$, Pierpaolo Correale ${ }^{2}$, Pierosandro Tagliaferri ${ }^{1}$ and Pierfrancesco Tassone ${ }^{1,3 *}$ \\ Department of Experimental and Clinical Medicine, "Magna Graecia" University and Medical Oncology Unit, T. Campanella Cancer Center, "Salvatore Venuta" \\ University Campus, Catanzaro, Italy \\ 2 Unit of Radiotherapy, Siena University Hospital, Siena, Italy \\ ${ }^{3}$ Sbarro Institute for Cancer Research and Molecular Medicine, Center for Biotechnology, College of Science and Technology, Temple University, Philadelphia, PA, \\ USA
}

\section{Edited by:}

Alessandra Romano, University of

Catania, Italy

Reviewed by:

Peiman Hematti, University of

Wisconsin-Madison, USA

Qaiser Bashir, The University of Texas

MD Anderson Cancer Center, USA

*Correspondence:

Pierfrancesco Tassone, Unit of Medical Oncology, Department of Experimental and Clinical Medicine, Magna Graecia University, Viale

Europa, Catanzaro 88100 Italy

e-mail: tassone@unicz.it
Immunosuppressive cells have been reported to play an important role in tumor-progression mainly because of their capability to promote immune-escape, angiogenesis, and metastasis. Among them, myeloid-derived suppressor cells (MDSCs) have been recently identified as immature myeloid cells, induced by tumor-associated inflammation, able to impair both innate and adaptive immunity. While murine MDSCs are usually identified by the expression of $\mathrm{CD} 11 \mathrm{~b}$ and $\mathrm{Gr} 1$, human MDSCs represent a more heterogeneous population characterized by the expression of CD33 and CD11b, low or no HLA-DR, and variable CD14 and CD15. In particular, the last two may alternatively identify monocyte-like or granulocytelike MDSC subsets with different immunosuppressive properties. Recently, a substantial increase of MDSCs has been found in peripheral blood and bone marrow (BM) of multiple myeloma $(\mathrm{MM})$ patients with a role in disease progression and/or drug resistance. Pre-clinical models recapitulating the complexity of the MM-related BM microenvironment (BMM) are major tools for the study of the interactions between MM cells and cells of the BMM (including MDSCs) and for the development of new agents targeting MM-associated immune-suppressive cells. This review will focus on current strategies for human MDSCs generation and investigation of their immunosuppressive function in vitro and in vivo, taking into account the relevant relationship occurring within the MM-BMM. We will then provide trends in MDSC-associated research and suggest potential application for the treatment of MM.

Keywords: MDSC, myeloma, immunosuppression, cancer, pre-clinical models

\section{INTRODUCTION}

The immune system has the potential to selectively kill tumor cells avoiding normal tissue and to generate long-lasting memory, which prevents cancer onset or recurrence. However, even if some patients achieve long-lasting complete remissions, the clinical efficacy of immunotherapy is still limited. One possible explanation should be identified in the protective milieu provided by tumor-associated inflammation and tumor-infiltrating myeloid and lymphoid cells $(1,2)$. The critical role of inflammation in cancer development and progression has been recognized over 150 years ago by Rudolf Virchow; however, only recently, chronic inflammation has been found to induce immunosuppression and has been associated with the development of cancer and other diseases (3-5). In the inflammatory response, myeloid effectors are the first cells attracted and recruited in the site of injury (6). Indeed, in cancer, these cells are represented by neutrophils, macrophages, dendritic cells (DCs), and the highly immunosuppressive myeloidderived suppressor cells (MDSCs) (7). MDSCs are a heterogeneous population of immature myeloid cells generated in the bone marrow (BM) of healthy subjects that normally differentiate in mature myeloid cells without inducing immunosuppression (7). However, in pathologic conditions such as cancer, trauma, or other diseases characterized by chronic inflammation, these cells undergo abnormal expansion, are blocked in differentiation and accumulate in different sites including BM, spleen, liver, and tumor site $(8,9)$, sustaining (or even worsening) preexisting tumor-driven inflammation and inducing tumor-progression, neovascularization, and immune-escape $(7,10-12)$.

In the last decade, several studies have focused on the role of MDSCs in the regulation of immune system in solid tumors while little is reported on the role of MDSCs in hematologic malignancies, including multiple myeloma (MM) (13). MM is an incurable disease characterized by accumulation of malignant plasma cells within the BM. The interplay between MM cells and cells of the BM microenvironment (BMM) is tough to be the cause, of two widely recognized hallmarks of MM: bone disease and general immunosuppression (14-16). Recently, it has been disclosed a major role for MDSCs in MM pathobiology. Indeed, different authors demonstrated an increase of MDSCs in both peripheral blood and BM of MM patients $(9,17,18)$. Moreover, it was reported that in addition to their immunosuppressive activity, MDSCs have the potential to differentiate in functional osteoclasts thus contributing to the formation of osteolytic lesions $(19,20)$. 
This review provides an overview on current pre-clinical approaches used to study human MDSCs in vitro and in vivo, with a particular focus on MM-associated MDSCs. We will also summarize the mechanism and the molecular pathways involved in MDSC-dependent immune-dysfunction and potential translational applications of MDCSs for the therapy of MM.

\section{IMMUNOPHENOTYPE OF MDSCS}

Myeloid-derived suppressor cells were firstly identified in tumorbearing mice on the basis of their suppressive function. Indeed, these cells lacked any surface marker specifically expressed by myeloid mature cells such as monocytes, macrophages, or DCs (21), even if morphologically they resembled granulocytes or monocytes. Further works in mice, aimed to characterize their immunophenotype, identified MDSCs as cells positive to granulocyte receptor (Gr1) and CD11b (22). The mAb used to identify $\mathrm{Gr} 1$, however, is able to bind the same epitope of two different molecules belonging to the lymphocyte superfamily (Ly)-6, Ly-6C, and Ly-6G, mainly expressed on monocytes and neutrophils, respectively. This led to the identification of two sub-groups of murine MDSCs, reflecting differences in term of both morphology and immunosuppressive function: CD11b ${ }^{+}$Ly-6C ${ }^{+}$Ly-6G ${ }^{-}$monocytic (Mo)-MDSCs, with a monocyte-like morphology, mainly expressing the inducible form of nitric oxide synthase (iNOS); and CD11b ${ }^{+}$Ly-6C Ly-6G $^{-}$granulocytic (G)-MDSCs [or polymorphonuclear (PMN)-MDSCs] with a granulocyte-like morphology expressing high levels of arginase 1 (ARG1) $(23,24)$.

Unlike murine MDSCs, the human MDSCs are less defined, lacking a Gr1 homologous. Commonly, MDSCs are defined as $\mathrm{CD}_{11 \mathrm{~b}^{+}} \mathrm{CD}^{+} 3^{+}$HLA-DR ${ }^{\text {low/- }}$ cells not expressing markers of mature myeloid or lymphoid cells. As in mice, two main subsets of MDSCs could be identified: $\mathrm{CD} 15^{+} \mathrm{CD} 14^{-} \mathrm{CD} 11 \mathrm{~b}^{+}$ $\mathrm{CD}_{3}{ }^{+}$HLA-DR $^{\text {low/- }}$ G-MDSCs and CD15 ${ }^{-} \mathrm{CD}^{+}{ }^{+} \mathrm{CD} 11 \mathrm{~b}^{+}$ $\mathrm{CD}^{+}{ }^{+}$HLA-DR ${ }^{\text {low/- }}$ Mo-MDSCs $(7,25,26)$. Furthermore, human MDSCs are extremely heterogeneous and recently different tumors were reported to generate MDSCs identified by different phenotypes (27). New markers are currently under investigation in order to better clarify their phenotype, subsets, and function. Among them, the expression of IL-4Ra and the VEGF receptors 1 and 2, on Mo-MDSCs in particular, have been associated with immunosuppressive and angiogenetic potential, respectively (7, 22). As regard to morphology, human MDSCs resemble granulocytes or monocytes at different maturation stages (28) and in cancer patients their number have been reported to directly correlate with neutrophil count (29). Taking into account the prognostic and predictive role played by neutrophil count and chronic inflammation in different malignancies (30-33), the key role of these cells in cancer patients is an emerging issue.

In MM, few reports $(9,17,18)$ identified MDSCs as CD11b ${ }^{+}$ $\mathrm{CD}^{+}{ }^{+} \mathrm{HLA}^{-D R^{\text {low/ }}-}$ cells in both peripheral blood and BM. G-MDSC resulted to be the most up-regulated and immunosuppressive subpopulation, while contrasting results were observed regarding the Mo-MDSCs. This should be due to differences in phenotypic profile, which identifies Mo-MDSCs. Indeed, while most of authors recognized G-MDSCs as CD15 ${ }^{+} \mathrm{CD} 14^{-} \mathrm{CD} 11 \mathrm{~b}^{+}$ $\mathrm{CD}^{+}{ }^{+}$HLA-DR ${ }^{\text {low/- }}$ cells, Mo-MDSCs have been alternatively identified as $\mathrm{CD}_{14}{ }^{+} \mathrm{CD}_{11 \mathrm{~b}^{+}} \operatorname{HLA}^{-D R}{ }^{\text {low/- }}(9,18)$ or $\mathrm{CD} 14^{+}$

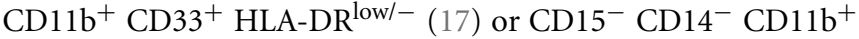
$\mathrm{CD}^{+} 3^{+}$cells $(9)$. Of note, in a previous report (34), Mo-MDSCs identified as $\mathrm{CD}_{14}{ }^{+}$HLA-DR ${ }^{\text {low/- }}$ cells were found to be significantly higher in patients with $\mathrm{MM}$ as compared to healthy subjects.

On these bases, due to the lack of a unique surface markers signature for the identification of MDSCs, functional suppressive assays remain essential.

\section{MDSCS FUNCTION AND ROLE IN TUMOR-PROGRESSION}

Myeloid-derived suppressor cells inhibit the anti-tumor immune response by multiple mechanisms, probably mostly triggered by direct cell-to-cell contact and involving cell surface receptors and short-lived mediators (Figure 1). Among others, the metabolism of L-arginine was the first identified mechanism for MDSCs immunosuppression $(35,36)$. Specifically, L-arginine serves as a substrate for iNOs (generating NO and citrulline) and ARG1 (producing urea and ornithine). The up-regulation of both enzymes in MDSCs lead to a shortage of the non-essential amino acid in tumor microenvironment, and consequently to the impairment of $\mathrm{T}$ cell function. Indeed, $\mathrm{T}$ lymphocytes depend on arginine for proliferation, $\mathrm{CD} 3 \zeta$ expression, and development of memory (37, 38 ). Furthermore, the increased NO production leads to suppression of $\mathrm{T}$ cell function through the inhibition of IL-2 downstream pathway $(39,40)$. An additional and related finding is that, MDSCs could also mediate the depletion of cystine and cysteine from tumor microenvironment, thus further limiting antigen-driven $\mathrm{T}$ cell activation (41).

A further hallmark of MDSC-dependent immunosuppression relies on the production of reactive oxygen species (ROS). Indeed, different studies report MDSCs from both tumor-bearing mice and cancer patients to produce a huge amount of $\operatorname{ROS}(23,42,43)$ that, in turn, reduce $\mathrm{CD} 3 \zeta$ expression and antigen specific $\mathrm{T}$ cell proliferation (44). ROS production by MDSC is sustained by the inflammatory tumor microenvironment, enriched, among others, in IL-10, IL-6, and TGF-beta, as well as by the cell-to-cell contact with lymphocytes $(37,44)$.

The contemporary presence of $\mathrm{NO}$ and superoxide in tumor microenvironment may lead to the production of peroxynitrite, which in turn induces the nitration of different amino acids such as tyrosine, tryptophan, cysteine, and methionine (45). Nitration of T cell receptor (TCR) and CD8 molecules results in a physical modification of the receptor that alters the binding to $\mathrm{MHC}$, thus impairing the capability of $\mathrm{T}$ cells to respond to antigen specific stimuli (46).

Recently, some authors (47) reported a new mechanism by which MDSCs inhibit the immune response against cancer. They found that MDSCs are able to down-regulate L-selectine (CD62L) levels on naïve $\mathrm{T}$ cells through their membrane expression of ADAM17. This event, in turn, decreases the capability of T cells to migrate to the tumor site where they would be activated.

A further mechanism of immune regulation by MDSCs relies on their capability to induce regulatory $\mathrm{T}$ cells (T-regs). Indeed, different studies report that MDSCs promote the clonal expansion of antigen specific natural T-regs and induce the conversion of naïve $\mathrm{T}$ helper cells into inducible T-regs, through a mechanism dependent on CD40-CD40L interaction; on the secretion of 


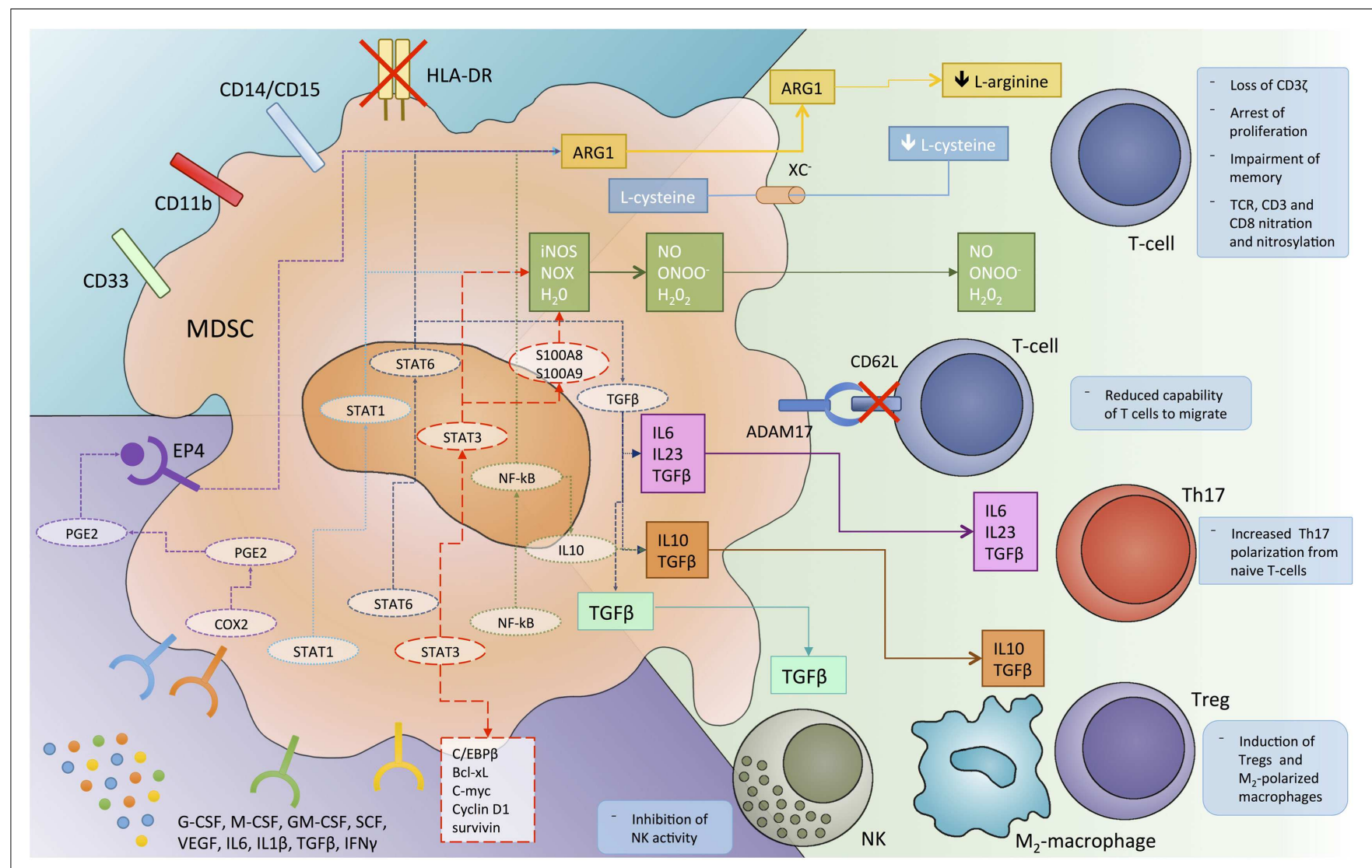

FIGURE 1 |The different mechanisms by which myeloid-derived suppressor cells (MDSC) inhibit immune system response and the molecular pathways involved in this immunosuppressive function. ADAM17, disintegrin and metalloproteinase domain-containing protein

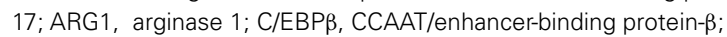
COX, cyclooxygenase; EP4, prostaglandin receptor E4; iNOS, inducible nitric oxide synthase; NK, natural killer cells; NO, nitric oxide; NOX, NADPH oxidase; PGE2, prostaglandin E2; ROS, reactive oxygen species; STAT, signal transducer and activator of transcription; TCR, T cell receptor; TGF $\beta$, transforming growth factor- $\beta$; T-regs, regulatory $T$ cells; VEGF, vascular endothelial growth factor; $\mathrm{Xc}^{-}$, cystine-glutamate transporter. cytokines such as IFN-gamma, IL-10, and TGF-beta; and on the overexpression of ARG1 (37, 48-50).

More recently, MDSCs have been reported to promote Th17 differentiation and IL-17A production (51). Th17 development was shown to be dependent on IL-1b/IL-6/IL-23 and NO production by MDSCs in both tumor-bearing mice and cancer patients (52-54). To better understand the paradoxical induction of "proinflammatory" Th17 by "immunosuppressive" MDSCs, it should be noted that Th17 cells play a role in both tumor-progression and induction of immunosuppression. Indeed, these cells promote chronic inflammation, DNA damage, and tumor-associated angiogenesis, and on the other hand promote the local recruitment of other inflammatory cells (including MDSCs) and inhibit immune response $(51,55,56)$.

A further immunosuppressive mechanism relies on the crosstalk between MDSCs and tumor-associated macrophages (TAMs) (57, 58). This strict interplay leads to a microenvironment enrichment in immune-regulatory cytokines such as IL-10, IL6 , IL-1b, VEGF, and to an immunosuppressive M2 polarization of macrophages. These cells also promote tumor-progression through different non-immune mechanism and in MM, in particular, are reported to induce cancer cell proliferation, drug resistance, and angiogenesis $(59,60)$.

Finally, emerging evidence suggests that MDSCs may promote immune-escape also by suppressing NK activity, overexpressing programmed death ligands (PD-L1 and PD-L2) and releasing IL-10 and indoleamine 2,3-dioxygenase (IDO) in the tumor microenvironment $(37,61,62)$.

\section{MOLECULAR REGULATORS OF MDSCS DEVELOPMENT AND FUNCTION}

The tumor-associated microenvironment produces several factors involved in myelopoiesis and impairs the myeloid differentiation. Among them, granulocyte-macrophage colony-stimulating factor (GM-CSF), G-CSF, M-CSF, stem cell factor, VEGF, and IL-3 are the most recognized molecules involved in MDSC generation $(27,63)$. Furthermore, a huge amount of cytokines and chemokines released by tumor cells or tumor-surrounding cells including IL-1 $\beta$, IL-4, IL-6, IL-10, IFN-gamma, TGF-beta, CCL2, CCL5, S100A8, and S100A9, are reported to reprogram immature myeloid cells to became immunosuppressive MDSCs and to attract them in the tumor microenvironment $(7,64,65)$. All these soluble 
mediators regulate MDSC function through the activation of different downstream signaling pathways, such as Jak/Stat, NF- $\kappa$ B, cyclooxygenase 2 (COX-2), and PGE2 (27, 66). Furthermore, recent evidence supports the hypothesis that a major role in this regulatory network is played by non-coding RNAs including micro-RNAs (miRNAs) and long non-coding RNAs (lncRNAs) (67-69).

\section{STAT FAMILY}

The signal transducer and activator of transcription (Stat) 3 plays, among other Stat family members, a major role in modulating MDSC function. In myeloid cells, Stat3 promotes the expression of different anti-apoptotic and pro-proliferative factors, such as Bcl-xL, c-myc, cyclin D1 and survivin, and prevent myeloid cells differentiation and maturation $(66,70)$. Stat 3 induces the up-regulation of the calcium-binding pro-inflammatory proteins S100A9 and S100A8. Some authors reported that Stat3-dependent S100A9 up-regulation enhances MDSC generation in vitro and that the immune system of mice lacking S100A9 have a greater ability to reject the tumor implant (71). The mechanism is still not fully understood, however, it is thought that the heterodimer S100A8/S100A9 is involved in ROS generation through NAPDH oxidase (Nox2) complex and that ROS, in turn, impairs myeloid cells differentiation (71). Moreover, STAT3 up-regulates two components of the Nox 2 complex, $\mathrm{p} 47^{\text {phox }}$, and gp91 ${ }^{\text {phox }}$, thus directly contributing to the increase in ROS production by MDSCs (72). Stat3 is also reported to interact with $\mathrm{C} / \mathrm{EBP} \beta$, a transcription factor involved in myelopoiesis and control of differentiation and proliferation of myeloid progenitors. The latter could be explained, at least in part, by the capability of activated Stat3 to induce cmyc expression due to the increased binding of $\mathrm{C} / \mathrm{EBP} \beta$ to $\mathrm{Myc}$ promoter $(65,73)$.

Among the other members of the Stat family, Stat1 and Stat6 play a key role in MDSC activation and immunosuppressive function. Stat 1 is activated by both IFN- $\gamma$ and IL- $1 \beta$ and is involved in the expression of ARG1 and iNOS. Indeed, MDSCs from mice knock-down for STAT1 are unable to inhibit T lymphocyte activation due to a lack in up-regulation of iNOS or ARG1 (74).

IL-4 or IL-13 binding to the CD124 leads to the activation of Stat6, which, in turn, induces the expression of arginase and the production of TGF $\beta$ by MDSCs, thus contributing to the instauration of an immune-permissive microenvironment (75-77).

\section{NF-кB}

The NF- $\kappa$ B activity has been reported to be critical for the immunosuppressive capability of MDSCs. Toll-like receptors (TLR) via myeloid differentiation primary response gene (MyD) 88 and IL- $1 \beta$ are fundamental activators of NF- $\kappa B$ signaling and lead to the production and secretion of Th2 cytokines, IL-10, and ARG1 (66). Recently, it has been demonstrated (78) a Stat3dependent activation of the non-canonical NF- $\kappa B$ pathway that, in turn, induces the transcription of IDO in MDSCs, thus elucidating a new mechanism for $\mathrm{T}$ cell immunity inhibition.

\section{PGE2 AND COX-2}

Prostaglandin E2 is an eicosanoid that act as both proinflammatory and immunosuppressive molecule. Its synthesis is COX-2 dependent and its signaling relies on the receptor E-prostanoid (EP) 4, which once activated induce ARG1 upregulation in MDSCs (79-81). EP2-knockout mice inoculated with 4T1 mammary carcinoma presented a reduced number of infiltrating MDSCs, suggesting an important role for PGE2 in MDSC induction (66). Furthermore, others provided evidence (82) that the COX-2 inhibition, which is induced with dietary celecoxib in a mesothelioma murine model, prevents the expansion of MDSCs. Together these results highlight the crucial role played by the COX-2/PGE2 signaling in MDSCs function and differentiation.

\section{MICRO-RNAS}

Micro-RNAs are small non-coding RNAs able to regulate gene expression at the post-transcriptional level (83). Due to their critical role in tumor biology (84-86) and cancer-microenvironment interaction (87-90), these molecules have gained particular attention even as possible immune modulators $(91,92)$. Indeed, different studies identified several miRNAs involved in the complex network that regulate MDSCs development and function $(67,68)$.

MiR-223 was the first miRNAs associated to MDSCs (93). It has been discovered that increased PGE2 in the tumor microenvironment leads to miR-223 down-regulation in MDSCs and subsequent up-regulation of its target myeloid enhancer factor 2 (Mef2c), which promote MDSC survival and accumulation in tumor site (93). MiR-223 is involved also in myeloid cell differentiation by targeting nuclear factor I (NFI)-A and inducing differentiation of immature myeloid cells into mature granulocytes (94).

MiR-494 has been shown to be up-regulated in MDSCs by tumor-derived factors (especially from TGF- $\beta$ ). This miRNA revealed to sustain MDSC survival through down-regulation of PTEN and to promote tumor invasion and metastasis by regulating metalloproteinase (MMP) expression (95).

Contrasting observations were reported for miR-17-5p and miR-20a by two different studies. Specifically, some authors reported (96) that both miRNAs target AML1, leading to a downregulation of M-CSF receptor and, consequently, to an impairment of monocyte differentiation. On the contrary, others demonstrated (97) that the tumor microenvironment led to both miRNAs downregulation and that, according to their capability to target Stat3, their reduction leads to the up-regulation of Stat 3 itself and the activation of the Stat3-dependent immunosuppressive cascade.

Using miRNA microarray, miR-21 and miR-155 have been identified as the two most up-regulated miRNAs during the induction of MDSC differentiation from BM cells (98). This upregulation was further confirmed in tumor-bearing mice with a mechanism dependent on the presence of TGF $\beta$ in tumor microenvironment. By targeting SHIP-1 and PTEN, respectively, these miRNAs lead to Stat 3 activation and MDSC proliferation and activation. Conversely, melanoma and Lewis lung carcinoma grew faster in miR-155 knockout mice and these tumors showed an increased MDSC infiltration (99). This event appears dependent on the up-regulation of HIF- $1 \alpha$ (a direct target of miR$155)$ in $\mathrm{miR}-155^{-l-}$ mice that leads to the enhanced expression of different chemokines and cytokines promoting MDSC recruitment, immunosuppression, and neovascularization. These 
apparent conflicting results may be dependent on the great heterogeneity of MDSCs and on the capability of different tumors to induce predominantly one rather than another MDSC subset. Further studies will better elucidate the role of miRNAs in MDSC-mediated cancer-associated immunosuppression.

\section{IN VITRO AND IN VIVO APPROACHES FOR HUMAN MDSCS STUDY IN MULTIPLE MYELOMA}

It is becoming clear that the long-term success of cancer immunotherapy depends on the reprograming of the tumorassociated immune-permissive microenvironment. The great immunosuppressive potential of MDSC coupled with their capability to accumulate in tumor tissue, makes them attractive targets for the development of specific anticancer therapy. However, this relevant challenge requires the development of a stable model for the study of human MDSC response to different experimental conditions. In vitro, generation of murine MDSCs is a relatively easy process that uses embryonic, splenic, or BM myeloid progenitor cultured in a medium enriched with a combination of growth factor such as GM-CSF + G-CSF, GM-CSF + IL-6, or IL-13 (100, 101). However, this model is hampered by the interspecies differences in both surface marker and biology of immune cells (102); additionally, the possibilities to reproduce this model with human cells are low due to the poor availability of myeloid progenitors from healthy donors.

Recently, to overcome these issues, some authors developed a method to generate MDSCs from healthy donors' peripheral blood mononuclear cells (PBMCs) $(103,104)$. As a first step of development of their model, authors evaluated the capability of 100 tumor cell lines to induce MDSC generation from healthy donor PBMCs during a 7-day co-culture. MDSCs so generated were phenotypically characterized and the $\mathrm{CD}_{3}{ }^{+} \mathrm{CD} 11^{+} \mathrm{HLA}^{+} \mathrm{DR}^{-/ l o w}$ population was sorted and assayed for the capability to suppress autologous $\mathrm{T}$ cell proliferation in response to stimuli (104). A cytokine study was simultaneously performed to identify the main factors responsible for MDSCs' generation (103). The authors observed that a 7-day culture with the combination GM-CSF + IL6 was sufficient to generate a potent immunosuppressive CD33 ${ }^{+}$ MDSC population. Of note, MDSCs were also generated, even if to a lesser extent, by combining GM-CSF with cytokines such as IL-1 $\beta$, VEGF, TNF $\alpha$, and PGE2, providing thus evidence that the presence of an inflammatory microenvironment is mandatory for MDSC generation. Furthermore, cytokine-induced MDSCs, as their tumor-induced counterpart, cause immunosuppression through the up-regulation of ARG1, iNOS, VEGF, and TGF $\beta$ (103).

In subsequent years, this model has been used to demonstrate the capability of different MM cell lines to induce, in vitro, the generation of functional MDSCs from healthy donor PBMCs and from BM aspirates (18).

Unlike in vitro studies, all models currently available for in vivo study of MDSCs are murine models. Furthermore, only two different mouse models have been used to investigate the role of MDSCs in MM. One of them is the syngeneic 5TMM mouse model inoculated with either the 5T2MM or the 5T33MM cell lines (105). These cells home in the BM and recapitulate very closely the human disease (including BM-MM cells interactions and osteolytic lesions) (105). This was the first demonstration of MDSC presence and activity in MM.

The second model was obtained inoculating mice with syngeneic murine BCM, DP 42, and ATLN MM cell lines (9). Cells in this model home to BM, and allow investigation of MDSCs in the BM milieu. By using these models, the authors discovered that MDSC infiltration of BM occurs early after tumor inoculation while, in the subsequent weeks, the percentage of infiltrating MDSC slowly decreases due to the increase of malignant PCs. Furthermore, by using S100A9 knockout transgenic mice, which have an impaired MDSC response to cancer, it has been observed a significant delay in tumor growth, which was reverted by adoptive administration of MDSCs, thus evidencing the key role played by MDSCs in tumor escape from immune system. However, the lack of models that recapitulate the complex human MM milieu limits the study of human MDSC interaction with MM cells and other component of BM milieu, thus limiting, in a translational view, the study of agents that may target specifically human MM-associated BM cells (106).

The SCID-hu model has been realized in an attempt to overcome these limitations (107-110). In this model, a human fetal bone chip is implanted in SCID mice and subsequently, primary patient malignant cells or BMSC-dependent human plasma cell line INA- 6 are injected directly into the human bone implant. This model demonstrated to be suitable and reliable system to evaluate the anti-tumor activity of different drugs including different anti-inflammatory agents (108-116). This model appears to be a good candidate for the study of MDSCs, even if some immunological pitfalls should be taken into account: the allogeneic nature of BM cells respect to both primary cells or MM cell lines and the bone chips heterogeneity due to different gestational age at which they are collected (106). Both these caveats have been overcome by the use of the SCID-synth-hu model (117). This model is based on the implantation of a tridimensional bone-like polymeric scaffold into a SCID mouse and on the subsequent injection of the whole unselected cell population from BM aspirates into the implanted scaffold. This model has been successful used for preclinical evaluation of a variety of investigational agents (83-85, $106,117)$. The recapitulation of an autologous BMM potentially offers the best model to investigate the MM-associated immunosuppressive niche and the strict interplay between MM cells and immature myeloid progenitors, including MDSCs, thus representing a unique tool for the development and evaluation of immune-modulating agents in MM.

\section{TRANSLATIONAL OPPORTUNITIES IN MM}

Recently, MDSCs have been associated with immune-dysfunction in $\mathrm{MM}$ patients. Few reports $(9,17,18)$ demonstrated the great complexity of the microenvironment in which pro-inflammatory factors co-exist with immune-suppressive mediators, in a finely tuned balance that influences patients' outcome (118-120). Additionally, different pro-inflammatory cytokines including IL- $1 \beta$, IL6 , IL-17, TNF $\alpha$, and IL-23 as well as anti-inflammatory cytokines such as IL-10, TGF $\beta$, or VEGF have been reported to be upregulated in $\mathrm{MM}$ patients in both peripheral blood and $\mathrm{BM}$ (1, 121-123). This peculiar BMM, on one hand potently impairs the capability of resident myeloid progenitors to differentiate into 
DCs, macrophages, or granulocytes, and on the other reprograms mature myeloid cells to assume an immune-permissive phenotype (tolerogenic DCs, M2, N2) (7). Obviously, these events lead to a vicious circle in which MM cells drive inflammation and immunosuppression while both sustain and promote tumor growth (2, 124). To interrupt this sequence of events, different drugs are under investigation or already available in MM and other malignancies that may potentially interfere with MDSC activity and different steps (Table 1 ).

Histone-deacetylase inhibitors are a novel class of drugs involved in the epigenetic modulation of gene expression, which revealed to have great anti-tumor activity in $\operatorname{MM}(125,126)$. Additionally, these agents revealed different anti-inflammatory properties related to their capability to impair, among others, the IL-6/Jak/Stat and the NF-кB signaling (127). Some authors recently reported that the histone-deacetylase inhibitor (HDAC-i) valproic acid reduces the capability of M-MDSC to transdifferentiate into G-MDSC in cancer microenvironment and induces their differentiation into macrophages or DCs, thus demonstrating a novel opportunity for the selective targeting of these immunosuppressive cells (128). Along the same line, different authors (129, 130) reported on the capability of all-trans retinoic acid (ATRA), a natural metabolite of vitamin A, to promote MDSCs differentiation into mature myeloid cells with a mechanism dependent on ERK activation and ROS reduction. This effect was also reported in cancer patients, where ATRA administration in combination with a DC based improved the immune response to vaccination by reducing the level of MDSCs in peripheral blood (131).

Blocking the cytokines involved in the immunosuppressive microenvironment may contribute to the impairment of MDSCs activity and led to benefit for cancer patients. Treatment with the IL- $1 \beta$ inhibitors anakinra induced serum IL- 6 decrease together with a substantial increase of PFS in high-risk smoldering or indolent MM patients (132).

Myeloid-derived suppressor cells are associated with high levels of circulating VEGF (133), however, treatment with anti-VEGF drugs such as bevacizumab did not demonstrate to affect MDSC levels in peripheral blood while increased the levels of mature DCs $(134,135)$. Furthermore, it is conceivable that the presence of MDSCs may represent a resistance factors to the activity of this class of drugs $(30,136,137)$.
As previously described, MDSC survival and differentiation is strictly dependent on STAT3 activation, thus targeting the IL6/Jak/Stat pathway could represent an effective strategy to block them (2). Furthermore, this pathway has a clear relevance in MM pathobiology $(111,138)$ and the possibility to target at the same time both MM cells and their associated immunosuppressive cells is very attractive. Different agents, including monoclonal antibodies against IL-6 or IL-6 receptor, Jak inhibitors, and STAT3 inhibitors are presently under investigation (139), and other innovative approaches, such as miRNA therapy (88), are coming out from pre-clinical research.

A different approach aims to stimulate MDSC differentiation into mature cells and to limit their expansion. As shown before G/M/GM-CSF are among the most important soluble factors involved in both processes. Different authors reported a decrease of MDSCs in vivo after inhibition of these molecules, associated with a relevant tumor shrinkage (140-142). However, G- and GMCSF are widely used in different anti-cancer treatments and in MM patients: G-CSF is used to mobilize hematopoietic stem cells, while GM-CSF is often used to improve the efficacy of cancer vaccines $(143,144)$. Indeed, some authors reported (17) a significant increase in MDSC number in peripheral blood stem cells after G-CSF administration and hypothesized a detrimental effect on patients undergoing transplant. GM-CSF, instead, seems to be active both as an immune-adjuvant and as a MDSC inducer in a dose-dependent manner $(145,146)$. In our hands, however, GMCSF resulted to be mandatory for an efficient anti-tumor response both in vitro and cancer patients $(31,147,148)$, while the patient prognosis seemed to be related to systemic inflammation at baseline. Indeed, we hypothesized that GM-CSF administration could be detrimental in patients with a high neutrophil or monocyte count (and indirectly to MDSCs) at baseline, an event that could be related to the presence of a tumor (or its associated microenvironment) able to produce this kind of cytokines by itself and from which it depends for survival and progression. Further studies are still awaited to better clarify this apparent dualistic role of hematopoietic growth factors.

As a further attempt to reduce the immunosuppressive function of MDSCs different authors tried to down-regulate the expression of COX-2, ARG1, and iNOS and to reduce ROS formation. Celecoxib, a COX-2 selective non-steroidal anti-inflammatory drug

Table 1 | Pre-clinical and clinical agents targeting MDSCs

\begin{tabular}{|c|c|c|c|}
\hline Differentiation and expansion & Intracellular modulators & Function & Depletion \\
\hline ATRA & IL-6R blockers & ARG1 and iNOS inhibitors & Chemotherapeutic agents \\
\hline HDAC inhibitors & JAK inhibitors & PDE-5 inhibitors (tadalafil, sildenafil) & Capecitabine \\
\hline Blocking cytokines & STAT3 inhibitors & COX-2 inhibitors & Gemcitabine \\
\hline IL-1 $\beta$ (anakinra) & miRNAs & Celecoxib & Doxorubicin \\
\hline $\mathrm{IL}-6$ & & ROS inhibitors & IL-4R $\alpha$ aptamer \\
\hline G-CSF & & Bisphosphonates & \\
\hline M-CSF & & Zoledronate & \\
\hline GM-CSF & & & \\
\hline
\end{tabular}


(NSAID), has been reported to improve the efficacy of a DCbased immunotherapy and to reduce the tumor infiltration by MDSCs (82).

After demonstrating the capability of the phosphodiesterase- 5 (PDE-5) tadalafil, to down-regulate in vitro and in vivo MDSCdependent iNOS and Arg-1 (36), the same authors recently reported a case-report of a lenalidomide-resistant MM patients who achieved a reduction in MDSCs, and a 18-month lasting response with evident clinical benefits (149).

Bisphosphonates, such as zoledronic acid (ZOL), have been demonstrated to exert several effects and still represent interesting drugs in terms of anti-tumor and immune-stimulatory activity (150-157). Indeed, these agents revealed to impairs MDSCs at different levels and some authors (20) observed a decrease in the expansion of MM-induced MDSCs and a reduced capability to form osteoclasts after zoledronate treatment in mice. The mechanism responsible for this activity is thought to be dependent on the capability of zoledronate to decrease the activity of MMP9, thus reducing the bioavailability of VEGF and impairing the c-kit intracellular signaling (158-160).

A further strategy to improve cancer-associated immunosuppression consists in the selective depletion of MDSCs. Beyond the already known immunomodulatory capability of chemotherapeutic agents capecitabine and gemcitabine (124), and the recently discovered potential of doxorubicin, a drug that still play an important role in MM treatment, in selectively reducing MDSCs (161), some authors developed an RNA aptamer (162) able to block both murine or human IL-4 receptor $\alpha$ (IL-4R $\alpha$ ), critical for MDSC suppression function. The binding of the aptamer to its specific receptor led to MDSC depletion and tumor arrest of growth in vivo. Furthermore, others (163) recently developed an innovative method to selectively target MDSCs. By using a competitive peptide phage platform they identified peptides enriched in both M- and G-MDSCs. Subsequently, they fused the sequence of the selected peptides with the Fc portion of a murine IgG2b antibody to generate a peptibody. When used in vivo, these molecules, completely depleted circulating, intra-tumoral and intra-splenic MDSCs and induced a better tumor response compared to antiGr1 antibody. The main targets identified with this approach were found to be proteins bearing to the S100 family.

Finally, due to their major role in cancer-associated microenvironment $(164,165)$, miRNAs may represent a new frontier in the field of immunotherapeutic drugs (166). Unlike monoclonal antibodies or small inhibitor molecules already available, miRNAs have the great advantage to target pathways and network at multiple steps thus representing a powerful tool to target tumorinduced immune-dysfunction. As shown before, different miRNAs have already been reported to be involved in MDSC generation and function and other are currently under investigation (167). Several studies are presently ongoing to better define the future role of both miRNA replacement and inhibition in cancer therapy and immunotherapy making them a promise and a challenge for novel translational treatment strategies.

\section{CONCLUDING REMARIKS}

During the last decade, a growing effort has been devoted to understanding the role of MM-driven immunosuppression in reducing or preventing the efficacy of immunotherapy. Among others, MDSCs revealed to play a critical role in the generation of such immune dysfunctional microenvironment in different animal models and cancer patients. On these bases it is possible to speculate that the identification of molecular pathways involved in MDSC function will lead to the development of new tailored agents able to disrupt the tumor-host immunosuppressive interactions, thus improving the efficacy of both humoral and cellular immunotherapy. We now predict a new era for immunotherapy in MM, which will provide breakthrough improvements in the treatment of this important still incurable disease.

\section{ACKNOWLEDGMENTS}

This work has been supported by the Italian Association for Cancer Research (AIRC), PI: Pierfrancesco Tassone. "Special Program Molecular Clinical Oncology- 5 per mille” n. 9980, 2010/15.

\section{REFERENCES}

1. Rossi M, Botta C, Correale P, Tassone P, Tagliaferri P. Immunologic microenvironment and personalized treatment in multiple myeloma. Expert Opin Biol Ther (2013) 13(Suppl 1):S83-93. doi:10.1517/14712598.2013.799130

2. Draghiciu OLJ, Nijman HW, Daemen T. Myeloid derived suppressor cells - an overview of combat strategies to increase immunotherapy efficacy. Oncoimmunology (2014). doi:10.4161/21624011.2014.954829

3. Balkwill F, Mantovani A. Inflammation and cancer: back to Virchow? Lancet (2001) 357(9255):539-45. doi:10.1016/S0140-6736(00)04046-0

4. Bronstein-Sitton N, Cohen-Daniel L, Vaknin I, Ezernitchi AV, Leshem B, Halabi A, et al. Sustained exposure to bacterial antigen induces interferon-gammadependent $\mathrm{T}$ cell receptor zeta down-regulation and impaired $\mathrm{T}$ cell function. Nat Immunol (2003) 4(10):957-64. doi:10.1038/ni975

5. Bunt SK, Sinha P, Clements VK, Leips J, Ostrand-Rosenberg S. Inflammation induces myeloid-derived suppressor cells that facilitate tumor progression. J Immunol (2006) 176(1):284-90. doi:10.4049/jimmunol.176.1.284

6. Coussens LM, Werb Z. Inflammation and cancer. Nature (2002) 420(6917):860-7. doi:10.1038/nature01322

7. Gabrilovich DI, Ostrand-Rosenberg S, Bronte V. Coordinated regulation of myeloid cells by tumours. Nat Rev Immunol (2012) 12(4):253-68. doi:10.1038/ nri3175

8. Keskinov AA, Shurin MR. Myeloid regulatory cells in tumor spreading and metastasis. Immunobiology (2014). doi:10.1016/j.imbio.2014.07.017

9. Ramachandran IR, Martner A, Pisklakova A, Condamine T, Chase T, Vogl T, et al. Myeloid-derived suppressor cells regulate growth of multiple myeloma by inhibiting T cells in bone marrow. J Immunol (2013) 190(7):3815-23. doi:10.4049/jimmunol.1203373

10. Centuori SM, Trad M, LaCasse CJ, Alizadeh D, Larmonier CB, Hanke NT, et al. Myeloid-derived suppressor cells from tumor-bearing mice impair TGF-beta-induced differentiation of CD4+CD25+FoxP3+ Tregs from CD4+CD25-FoxP3- T cells. J Leukoc Biol (2012) 92(5):987-97. doi:10.1189/ jlb.0911465

11. Mantovani A, Sica A, Allavena P, Garlanda C, Locati M. Tumor-associated macrophages and the related myeloid-derived suppressor cells as a paradigm of the diversity of macrophage activation. Hum Immunol (2009) 70(5):325-30. doi:10.1016/j.humimm.2009.02.008

12. Yi H, Guo C, Yu X, Zuo D, Wang XY. Mouse CD11b+Gr-1+ myeloid cells can promote Th17 cell differentiation and experimental autoimmune encephalomyelitis. J Immunol (2012) 189(9):4295-304. doi:10.4049/ jimmunol.1200086

13. Romano A, Conticello C, Cavalli M, Vetro C, La Fauci A, Parrinello NL, et al. Immunological dysregulation in multiple myeloma microenvironment. Biomed Res Int (2014) 2014:198539. doi:10.1155/2014/198539

14. Ishitsuka K, Hideshima $T$, Neri P, Vallet S, Shiraishi N, Okawa Y, et al. p38 mitogen-activated protein kinase inhibitor LY2228820 enhances bortezomib-induced cytotoxicity and inhibits osteoclastogenesis in multiple myeloma; therapeutic implications. Br J Haematol (2008) 141(5):598-606. doi:10.1111/j.1365-2141.2008.07044.x 
15. Neri P, Kumar S, Fulciniti MT, Vallet S, Chhetri S, Mukherjee S, et al. Neutralizing B-cell activating factor antibody improves survival and inhibits osteoclastogenesis in a severe combined immunodeficient human multiple myeloma model. Clin Cancer Res (2007) 13(19):5903-9. doi:10.1158/1078-0432.CCR07-0753

16. Tai YT, Fulciniti M, Hideshima T, Song W, Leiba M, Li XF, et al. Targeting MEK induces myeloma-cell cytotoxicity and inhibits osteoclastogenesis. Blood (2007) 110(5):1656-63. doi:10.1182/blood-2007-03-081240

17. Favaloro J, Liyadipitiya T, Brown R, Yang S, Suen H, Woodland N, et al. Myeloid derived suppressor cells are numerically, functionally and phenotypically different in patients with multiple myeloma. Leuk Lymphoma (2014):1-8. doi:10.3109/10428194.2014.904511

18. Gorgun GT, Whitehill G, Anderson JL, Hideshima T, Maguire C, Laubach J, et al. Tumor-promoting immune-suppressive myeloid-derived suppressor cells in the multiple myeloma microenvironment in humans. Blood (2013) 121(15):2975-87. doi:10.1182/blood-2012-08-448548

19. Sawant A, Deshane J, Jules J, Lee CM, Harris BA, Feng X, et al. Myeloid-derived suppressor cells function as novel osteoclast progenitors enhancing bone loss in breast cancer. Cancer Res (2013) 73(2):672-82. doi:10.1158/0008-5472.CAN12-2202

20. Zhuang J, Zhang J, Lwin ST, Edwards JR, Edwards CM, Mundy GR, et al. Osteoclasts in multiple myeloma are derived from Gr-1+CD11b+myeloid-derived suppressor cells. PLoS One (2012) 7(11):e48871. doi:10.1371/journal.pone. 0048871

21. Bennett JA, Rao VS, Mitchell MS. Systemic bacillus Calmette-Guerin (BCG) activates natural suppressor cells. Proc Natl Acad Sci U S A (1978) 75(10):5142-4. doi:10.1073/pnas.75.10.5142

22. Talmadge JE, Gabrilovich DI. History of myeloid-derived suppressor cells. Nat Rev Cancer (2013) 13(10):739-52. doi:10.1038/nrc3581

23. Youn JI, Nagaraj S, Collazo M, Gabrilovich DI. Subsets of myeloid-derived suppressor cells in tumor-bearing mice. J Immunol (2008) 181(8):5791-802. doi:10.4049/jimmunol.181.8.5791

24. Peranzoni E, Zilio S, Marigo I, Dolcetti L, Zanovello P, Mandruzzato S, et al. Myeloid-derived suppressor cell heterogeneity and subset definition. Curr Opin Immunol (2010) 22(2):238-44. doi:10.1016/j.coi.2010.01.021

25. Wang Y, Gu X, Xiang J, Chen Z. Myeloid-derived suppressor cells participate in preventing graft rejection. Clin Dev Immunol (2012) 2012:731486. doi:10.1155/2012/731486

26. Zhang B, Wang Z, Wu L, Zhang M, Li W, Ding J, et al. Circulating and tumorinfiltrating myeloid-derived suppressor cells in patients with colorectal carcinoma. PLoS One (2013) 8(2):e57114. doi:10.1371/journal.pone.0057114

27. Trikha P, Carson WE III. Signaling pathways involved in MDSC regulation. Biochim Biophys Acta (2014) 1846(1):55-65. doi:10.1016/j.bbcan.2014.04.003

28. Brandau S, Trellakis S, Bruderek K, Schmaltz D, Steller G, Elian M, et al. Myeloid-derived suppressor cells in the peripheral blood of cancer patients contain a subset of immature neutrophils with impaired migratory properties. J Leukoc Biol (2011) 89(2):311-7. doi:10.1189/jlb.0310162

29. Ohki S, Shibata M, Gonda K, Machida T, Shimura T, Nakamura I, et al. Circulating myeloid-derived suppressor cells are increased and correlate to immune suppression, inflammation and hypoproteinemia in patients with cancer. Oncol Rep (2012) 28(2):453-8. doi:10.3892/or.2012.1812

30. Botta C, Barbieri V, Ciliberto D, Rossi A, Rocco D, Addeo R, et al. Systemic inflammatory status at baseline predicts bevacizumab benefit in advanced non-small cell lung cancer patients. Cancer Biol Ther (2013) 14(6):469-75. doi:10.4161/cbt.24425

31. Correale P, Botta C, Rotundo MS, Guglielmo A, Conca R, Licchetta A, et al. Gemcitabine, oxaliplatin, levofolinate, 5-fluorouracil, granulocytemacrophage colony-stimulating factor, and interleukin-2 (GOLFIG) versus FOLFOX chemotherapy in metastatic colorectal cancer patients: the GOLFIG2 multicentric open-label randomized phase III trial. J Immunother (2014) 37(1):26-35. doi:10.1097/CJI.0000000000000004

32. Kelkitli E, Atay H, Cilingir F, Guler N, Terzi Y, Ozatli D, et al. Predicting survival for multiple myeloma patients using baseline neutrophil/lymphocyte ratio. Ann Hematol (2014) 93(5):841-6. doi:10.1007/s00277-013-1978-8

33. Templeton AJ, Pezaro C, Omlin A, McNamara MG, Leibowitz-Amit R, VeraBadillo FE, et al. Simple prognostic score for metastatic castration-resistant prostate cancer with incorporation of neutrophil-to-lymphocyte ratio. Cancer (2014) 120:(21):3346-52. doi:10.1002/cncr.28890
34. Brimnes MK, Vangsted AJ, Knudsen LM, Gimsing P, Gang AO, Johnsen HE, et al. Increased level of both CD4+FOXP3 + regulatory T cells and CD14+HLA$\mathrm{DR}(-) /$ low myeloid-derived suppressor cells and decreased level of dendritic cells in patients with multiple myeloma. Scand J Immunol (2010) 72(6):540-7. doi:10.1111/j.1365-3083.2010.02463.x

35. Rodriguez PC, Quiceno DG, Zabaleta J, Ortiz B, Zea AH, Piazuelo MB, et al. Arginase I production in the tumor microenvironment by mature myeloid cells inhibits T-cell receptor expression and antigen-specific T-cell responses. Cancer Res (2004) 64(16):5839-49. doi:10.1158/0008-5472.CAN-04-0465

36. Serafini P, Meckel K, Kelso M, Noonan K, Califano J, Koch W, et al. Phosphodiesterase-5 inhibition augments endogenous antitumor immunity by reducing myeloid-derived suppressor cell function. J Exp Med (2006) 203(12):2691-702. doi:10.1084/jem.20061104

37. Nagaraj S, Gabrilovich DI. Regulation of suppressive function of myeloidderived suppressor cells by CD4+ T cells. Semin Cancer Biol (2012) 22(4):282-8. doi:10.1016/j.semcancer.2012.01.010

38. Rodriguez PC, Ochoa AC. Arginine regulation by myeloid derived suppressor cells and tolerance in cancer: mechanisms and therapeutic perspectives. Immunol Rev (2008) 222:180-91. doi:10.1111/j.1600-065X.2008.00608.x

39. Bingisser RM, Tilbrook PA, Holt PG, Kees UR. Macrophage-derived nitric oxide regulates T cell activation via reversible disruption of the Jak3/STAT5 signaling pathway. J Immunol (1998) 160(12):5729-34.

40. Mazzoni A, Bronte V, Visintin A, Spitzer JH, Apolloni E, Serafini P, et al. Myeloid suppressor lines inhibit $\mathrm{T}$ cell responses by an NO-dependent mechanism. J Immunol (2002) 168(2):689-95. doi:10.4049/jimmunol.168.2.689

41. Srivastava MK, Sinha P, Clements VK, Rodriguez P, Ostrand-Rosenberg S. Myeloid-derived suppressor cells inhibit T-cell activation by depleting cystine and cysteine. Cancer Res (2010) 70(1):68-77. doi:10.1158/0008-5472.CAN09-2587

42. Schmielau J, Finn OJ. Activated granulocytes and granulocyte-derived hydrogen peroxide are the underlying mechanism of suppression of t-cell function in advanced cancer patients. Cancer Res (2001) 61(12):4756-60.

43. Mantovani G, Maccio A, Madeddu C, Mura L, Gramignano G, Lusso MR, et al. Antioxidant agents are effective in inducing lymphocyte progression through cell cycle in advanced cancer patients: assessment of the most important laboratory indexes of cachexia and oxidative stress. J Mol Med (2003) 81(10):664-73. doi:10.1007/s00109-003-0476-1

44. Kusmartsev S, Nefedova Y, Yoder D, Gabrilovich DI. Antigen-specific inhibition of CD8+ T cell response by immature myeloid cells in cancer is mediated by reactive oxygen species. J Immunol (2004) 172(2):989-99. doi:10.4049/ jimmunol.172.2.989

45. Lu T, Ramakrishnan R, Altiok S, Youn JI, Cheng P, Celis E, et al. Tumorinfiltrating myeloid cells induce tumor cell resistance to cytotoxic $\mathrm{T}$ cells in mice. J Clin Invest (2011) 121(10):4015-29. doi:10.1172/JCI45862

46. Nagaraj S, Schrum AG, Cho HI, Celis E, Gabrilovich DI. Mechanism of T cell tolerance induced by myeloid-derived suppressor cells. J Immunol (2010) 184(6):3106-16. doi:10.4049/jimmunol.0902661

47. Hanson EM, Clements VK, Sinha P, Ilkovitch D, Ostrand-Rosenberg S. Myeloid-derived suppressor cells down-regulate L-selectin expression on CD4+ and CD8+ T cells. J Immunol (2009) 183(2):937-44. doi:10.4049/ jimmunol.0804253

48. Pan PY, Ma G, Weber KJ, Ozao-Choy J, Wang G, Yin B, et al. Immune stimulatory receptor CD40 is required for T-cell suppression and $\mathrm{T}$ regulatory cell activation mediated by myeloid-derived suppressor cells in cancer. Cancer Res (2010) 70(1):99-108. doi:10.1158/0008-5472.CAN-09-1882

49. Huang B, Pan PY, Li Q, Sato AI, Levy DE, Bromberg J, et al. Gr-1+CD115+ immature myeloid suppressor cells mediate the development of tumor-induced T regulatory cells and T-cell anergy in tumor-bearing host. Cancer Res (2006) 66(2):1123-31. doi:10.1158/0008-5472.CAN-05-1299

50. Serafini P, Mgebroff S, Noonan K, Borrello I. Myeloid-derived suppressor cells promote cross-tolerance in B-cell lymphoma by expanding regulatory T cells. Cancer Res (2008) 68(13):5439-49. doi:10.1158/0008-5472.CAN07-6621

51. Manjili MH, Wang XY, Abrams S. Evolution of our understanding of myeloid regulatory cells: from MDSCs to Mregs. Front Immunol (2014) 5:303. doi:10. 3389/fimmu.2014.00303

52. Obermajer N, Wong JL, Edwards RP, Chen K, Scott M, Khader S, et al. Induction and stability of human Th17 cells require endogenous NOS2 
and cGMP-dependent NO signaling. $J$ Exp Med (2013) 210(7):1433-45. doi:10.1084/jem.20121277

53. Jiao ZJ, Gao JJ, Hua SH, Chen DY, Wang WH, Wang H, et al. Correlation between circulating myeloid-derived suppressor cells and Th17 cells in esophageal cancer. World J Gastroenterol (2012) 18(38):5454-61. doi:10.3748/ wig.v18.i38.5454

54. Yazawa T, Shibata M, Gonda K, Machida T, Suzuki S, Kenjo A, et al. Increased IL17 production correlates with immunosuppression involving myeloid-derived suppressor cells and nutritional impairment in patients with various gastrointestinal cancers. Mol Clin Oncol (2013) 1(4):675-9. doi:10.3892/mco.2013.134

55. Correale P, Rotundo MS, Botta C, Del Vecchio MT, Ginanneschi C, Licchetta A, et al. Tumor infiltration by T lymphocytes expressing chemokine receptor 7 (CCR7) is predictive of favorable outcome in patients with advanced colorectal carcinoma. Clin Cancer Res (2012) 18(3):850-7. doi:10.1158/1078-0432.CCR10-3186

56. Correale P, Rotundo MS, Botta C, Del Vecchio MT, Tassone P, Tagliaferri P. Tumor infiltration by chemokine receptor $7($ CCR7)(+) T-lymphocytes is a favorable prognostic factor in metastatic colorectal cancer. Oncoimmunology (2012) 1(4):531-2. doi:10.4161/onci.19404

57. Ostrand-Rosenberg S, Sinha P, Beury DW, Clements VK. Cross-talk between myeloid-derived suppressor cells (MDSC), macrophages, and dendritic cells enhances tumor-induced immune suppression. Semin Cancer Biol (2012) 22(4):275-81. doi:10.1016/j.semcancer.2012.01.011

58. Beury DW, Parker KH, Nyandjo M, Sinha P, Carter KA, Ostrand-Rosenberg S. Cross-talk among myeloid-derived suppressor cells, macrophages, and tumor cells impacts the inflammatory milieu of solid tumors. J Leukoc Biol (2014). doi:10.1189/jlb.3A0414-210R

59. Kim J, Denu RA, Dollar BA, Escalante LE, Kuether JP, Callander NS, et al. Macrophages and mesenchymal stromal cells support survival and proliferation of multiple myeloma cells. Br J Haematol (2012) 158(3):336-46. doi:10.1111/j.1365-2141.2012.09154.x

60. Berardi S, Ria R, Reale A, De Luisi A, Catacchio I, Moschetta M, et al. Multiple myeloma macrophages: pivotal players in the tumor microenvironment. $J$ Oncol (2013) 2013:183602. doi:10.1155/2013/183602

61. Monu NR, Frey AB. Myeloid-derived suppressor cells and anti-tumor T cells: a complex relationship. Immunol Invest (2012) 41(6-7):595-613. doi:10.3109/ 08820139.2012 .673191

62. Greten TF, Manns MP, Korangy F. Myeloid derived suppressor cells in human diseases. Int Immunopharmacol (2011) 11(7):802-7. doi:10.1016/j.intimp. 2011.01.003

63. Sica A, Bronte V. Altered macrophage differentiation and immune dysfunction in tumor development. J Clin Invest (2007) 117(5):1155-66. doi:10.1172/ JCI31422

64. Gallina G, Dolcetti L, Serafini P, De Santo C, Marigo I, Colombo MP, et al. Tumors induce a subset of inflammatory monocytes with immunosuppressive activity on CD8+ T cells. J Clin Invest (2006) 116(10):2777-90. doi:10.1172/JCI28828

65. Marigo I, Bosio E, Solito S, Mesa C, Fernandez A, Dolcetti L, et al. Tumorinduced tolerance and immune suppression depend on the C/EBPbeta transcription factor. Immunity (2010) 32(6):790-802. doi:10.1016/j.immuni.2010. 05.010

66. Condamine T, Gabrilovich DI. Molecular mechanisms regulating myeloidderived suppressor cell differentiation and function. Trends Immunol (2011) 32(1):19-25. doi:10.1016/j.it.2010.10.002

67. El Gazzar M. microRNAs as potential regulators of myeloid-derived suppressor cell expansion. Innate Immun (2014) 20(3):227-38. doi:10.1177/ 1753425913489850

68. Tian J, Rui K, Wang S. Roles of miRNAs in regulating the differentiation and maturation of myeloid-derived suppressor cells. Med Hypotheses (2014) 83(2):151-3. doi:10.1016/j.mehy.2014.05.006

69. Heward JA, Lindsay MA. Long non-coding RNAs in the regulation of the immune response. Trends Immunol (2014) 35(9):408-19. doi:10.1016/j.it.2014. 07.005

70. Yu H, Pardoll D, Jove R. STATs in cancer inflammation and immunity: a leading role for STAT3. Nat Rev Cancer (2009) 9(11):798-809. doi:10.1038/nrc2734

71. Cheng P, Corzo CA, Luetteke N, Yu B, Nagaraj S, Bui MM, et al. Inhibition of dendritic cell differentiation and accumulation of myeloid-derived suppressor cells in cancer is regulated by S100A9 protein. J Exp Med (2008) 205(10):2235-49. doi:10.1084/jem.20080132
72. Corzo CA, Condamine T, Lu L, Cotter MJ, Youn JI, Cheng P, et al. HIFlalpha regulates function and differentiation of myeloid-derived suppressor cells in the tumor microenvironment. J Exp Med (2010) 207(11):2439-53. doi:10.1084/jem.20100587

73. Zhang H, Nguyen-Jackson H, Panopoulos AD, Li HS, Murray PJ, Watowich SS. STAT3 controls myeloid progenitor growth during emergency granulopoiesis. Blood (2010) 116(14):2462-71. doi:10.1182/blood-2009-12-259630

74. Kusmartsev S, Gabrilovich DI. STAT1 signaling regulates tumor-associated macrophage-mediated $\mathrm{T}$ cell deletion. J Immunol (2005) 174(8):4880-91. doi:10.4049/jimmunol.174.8.4880

75. Sinha P, Clements VK, Ostrand-Rosenberg S. Interleukin-13-regulated M2 macrophages in combination with myeloid suppressor cells block immune surveillance against metastasis. Cancer Res (2005) 65(24):11743-51. doi:10.1158/ 0008-5472.CAN-05-0045

76. Bronte V, Serafini P, De Santo C, Marigo I, Tosello V, Mazzoni A, et al. IL4-induced arginase 1 suppresses alloreactive $\mathrm{T}$ cells in tumor-bearing mice. J Immunol (2003) 170(1):270-8. doi:10.4049/jimmunol.170.1.270

77. Terabe M, Matsui S, Park JM, Mamura M, Noben-Trauth N, Donaldson DD, et al. Transforming growth factor-beta production and myeloid cells are an effector mechanism through which CD1d-restricted T cells block cytotoxic $\mathrm{T}$ lymphocyte-mediated tumor immunosurveillance: abrogation prevents tumor recurrence. J Exp Med (2003) 198(11):1741-52. doi:10.1084/jem. 20022227

78. Yu J, Wang Y, Yan F, Zhang P, Li H, Zhao H, et al. Noncanonical NFkappaB activation mediates STAT3-stimulated IDO upregulation in myeloidderived suppressor cells in breast cancer. J Immunol (2014) 193(5):2574-86. doi:10.4049/jimmunol.1400833

79. Khaled YS, Ammori BJ, Elkord E. Myeloid-derived suppressor cells in cancer: recent progress and prospects. Immunol Cell Biol (2013) 91(8):493-502. doi:10.1038/icb.2013.29

80. Rodriguez PC, Hernandez CP, Quiceno D, Dubinett SM, Zabaleta J, Ochoa $\mathrm{JB}$, et al. Arginase I in myeloid suppressor cells is induced by COX-2 in lung carcinoma. J Exp Med (2005) 202(7):931-9. doi:10.1084/jem.20050715

81. Zhang Y, Liu Q, Zhang M, Yu Y, Liu X, Cao X. Fas signal promotes lung cancer growth by recruiting myeloid-derived suppressor cells via cancer cell-derived PGE2. J Immunol (2009) 182(6):3801-8. doi:10.4049/jimmunol.0801548

82. Veltman JD, Lambers ME, van Nimwegen M, Hendriks RW, Hoogsteden HC, Aerts JG, et al. COX-2 inhibition improves immunotherapy and is associated with decreased numbers of myeloid-derived suppressor cells in mesothelioma. Celecoxib influences MDSC function. BMC Cancer (2010) 10:464. doi:10.1186/1471-2407-10-464

83. Tagliaferri P, Rossi M, Di Martino MT, Amodio N, Leone E, Gulla A, et al. Promises and challenges of MicroRNA-based treatment of multiple myeloma. Curr Cancer Drug Targets (2012) 12(7):838-46. doi:10.2174/ 156800912802429355

84. Di Martino MT, Leone E, Amodio N, Foresta U, Lionetti M, Pitari MR, et al. Synthetic miR-34a mimics as a novel therapeutic agent for multiple myeloma: in vitro and in vivo evidence. Clin Cancer Res (2012) 18(22):6260-70. doi:10.1158/1078-0432.CCR-12-1708

85. Amodio N, Leotta M, Bellizzi D, Di Martino MT, D’Aquila P, Lionetti M, et al. DNA-demethylating and anti-tumor activity of synthetic miR-29b mimics in multiple myeloma. Oncotarget (2012) 3(10):1246-58.

86. Leotta M, Biamonte L, Raimondi L, Ronchetti D, Di Martino MT, Botta C, et al. A p53-dependent tumor suppressor network is induced by selective miR-125a5p inhibition in multiple myeloma cells. J Cell Physiol (2014) 229(12):2106-16. doi:10.1002/jcp. 24669

87. Leone E, Morelli E, Di Martino MT, Amodio N, Foresta U, Gulla A, et al. Targeting miR-21 inhibits in vitro and in vivo multiple myeloma cell growth. Clin Cancer Res (2013) 19(8):2096-106. doi:10.1158/1078-0432.CCR-12-3325

88. Amodio N, Bellizzi D, Leotta M, Raimondi L, Biamonte L, D'Aquila P, et al. miR-29b induces SOCS-1 expression by promoter demethylation and negatively regulates migration of multiple myeloma and endothelial cells. Cell Cycle (2013) 12(23):3650-62. doi:10.4161/cc.26585

89. Rossi M, Pitari MR, Amodio N, Di Martino MT, Conforti F, Leone E, et al. miR-29b negatively regulates human osteoclastic cell differentiation and function: implications for the treatment of multiple myeloma-related bone disease. J Cell Physiol (2013) 228(7):1506-15. doi:10.1002/jcp.24306

90. Raimondi L, Amodio N, Di Martino MT, Altomare E, Leotta M, Caracciolo $\mathrm{D}$, et al. Targeting of multiple myeloma-related angiogenesis by 
miR-199a-5p mimics: in vitro and in vivo anti-tumor activity. Oncotarget (2014) 5(10):3039-54.

91. Raisch J, Darfeuille-Michaud A, Nguyen HT. Role of microRNAs in the immune system, inflammation and cancer. World J Gastroenterol (2013) 19(20):2985-96. doi:10.3748/wjg.v19.i20.2985

92. Rebane A, Akdis CA. MicroRNAs: essential players in the regulation of inflammation. J Allergy Clin Immunol (2013) 132(1):15-26. doi:10.1016/j.jaci.2013. 04.011

93. Liu Q, Zhang M, Jiang X, Zhang Z, Dai L, Min S, et al. miR-223 suppresses differentiation of tumor-induced $\mathrm{CD} 11 \mathrm{~b}(+) \mathrm{Gr} 1(+)$ myeloid-derived suppressor cells from bone marrow cells. Int J Cancer (2011) 129(11):2662-73. doi:10.1002/ijc. 25921

94. Fazi F, Rosa A, Fatica A, Gelmetti V, De Marchis ML, Nervi C, et al. A minicircuitry comprised of microRNA-223 and transcription factors NFI-A and C/EBPalpha regulates human granulopoiesis. Cell (2005) 123(5):819-31. doi:10.1016/j.cell.2005.09.023

95. Liu Y, Lai L, Chen Q, Song Y, Xu S, Ma F, et al. MicroRNA-494 is required for the accumulation and functions of tumor-expanded myeloid-derived suppressor cells via targeting of PTEN. J Immunol (2012) 188(11):5500-10. doi:10.4049/jimmunol.1103505

96. Fontana L, Pelosi E, Greco P, Racanicchi S, Testa U, Liuzzi F, et al. MicroRNAs 17-5p-20a-106a control monocytopoiesis through AML1 targeting and M-CSF receptor upregulation. Nat Cell Biol (2007) 9(7):775-87. doi:10.1038/ ncb1613

97. Zhang M, Liu Q, Mi S, Liang X, Zhang Z, Su X, et al. Both miR-17-5p and miR-20a alleviate suppressive potential of myeloid-derived suppressor cells by modulating STAT3 expression. J Immunol (2011) 186(8):4716-24. doi:10.4049/jimmunol.1002989

98. Li L, Zhang J, Diao W, Wang D, Wei Y, Zhang CY, et al. MicroRNA-155 and MicroRNA-21 promote the expansion of functional myeloid-derived suppressor cells. J Immunol (2014) 192(3):1034-43. doi:10.4049/jimmunol. 1301309

99. Wang J, Yu F, Jia X, Iwanowycz S, Wang Y, Huang S, et al. MicroRNA-155 deficiency enhances the recruitment and functions of myeloid-derived suppressor cells in tumor microenvironment and promotes solid tumor growth. Int J Cancer (2014). doi:10.1002/ijc.29151

100. Obermajer N, Kalinski P. Generation of myeloid-derived suppressor cells using prostaglandin E2. Transplant Res (2012) 1(1):15. doi:10.1186/2047-1440-1-15

101. Zhou Z, French DL, Ma G, Eisenstein S, Chen Y, Divino CM, et al. Development and function of myeloid-derived suppressor cells generated from mouse embryonic and hematopoietic stem cells. Stem Cells (2010) 28(3):620-32. doi:10.1002/stem.301

102. Leslie M. Biomedical research. Immunology uncaged. Science (2010) 327(5973):1573. doi:10.1126/science.327.5973.1573

103. Lechner MG, Liebertz DJ, Epstein AL. Characterization of cytokine-induced myeloid-derived suppressor cells from normal human peripheral blood mononuclear cells. J Immunol (2010) 185(4):2273-84. doi:10.4049/jimmunol. 1000901

104. Lechner MG, Megiel C, Russell SM, Bingham B, Arger N, Woo T, et al. Functional characterization of human $\mathrm{Cd} 33+$ and $\mathrm{Cd} 11 \mathrm{~b}+$ myeloid-derived suppressor cell subsets induced from peripheral blood mononuclear cells cocultured with a diverse set of human tumor cell lines. J Transl Med (2011) 9:90. doi:10.1186/1479-5876-9-90

105. Van Valckenborgh E, Schouppe E, Movahedi K, De Bruyne E, Menu E, De Baetselier $\mathrm{P}$, et al. Multiple myeloma induces the immunosuppressive capacity of distinct myeloid-derived suppressor cell subpopulations in the bone marrow. Leukemia (2012) 26(11):2424-8. doi:10.1038/leu.2012.113

106. Tassone P, Neri P, Burger R, Di Martino MT, Leone E, Amodio N, et al. Mouse models as a translational platform for the development of new therapeutic agents in multiple myeloma. Curr Cancer Drug Targets (2012) 12(7):814-22. doi:10.2174/156800912802429292

107. Urashima M, Chen BP, Chen S, Pinkus GS, Bronson RT, Dedera DA, et al. The development of a model for the homing of multiple myeloma cells to human bone marrow. Blood (1997) 90(2):754-65.

108. Tassone P, Neri P, Burger R, Savino R, Shammas M, Catley L, et al. Combination therapy with interleukin-6 receptor superantagonist Sant7 and dexamethasone induces antitumor effects in a novel SCID-hu In vivo model of human multiple myeloma. Clin Cancer Res (2005) 11(11):4251-8. doi:10.1158/1078-0432. CCR-04-2611
109. Tassone P, Neri P, Kutok JL, Tournilhac O, Santos DD, Hatjiharissi E, et al. A SCID-hu in vivo model of human Waldenstrom macroglobulinemia. Blood (2005) 106(4):1341-5. doi:10.1182/blood-2004-11-4477

110. Tassone P, Neri P, Carrasco DR, Burger R, Goldmacher VS, Fram R, et al. A clinically relevant SCID-hu in vivo model of human multiple myeloma. Blood (2005) 106(2):713-6. doi:10.1182/blood-2004-11-4477

111. Fulciniti M, Hideshima T, Vermot-Desroches C, Pozzi S, Nanjappa P, Shen Z, et al. A high-affinity fully human anti-IL-6 mAb, 1339, for the treatment of multiple myeloma. Clin Cancer Res (2009) 15(23):7144-52. doi:10.1158/10780432.CCR-09-1483

112. Fulciniti M, Tassone P, Hideshima T, Vallet S, Nanjappa P, Ettenberg SA, et al. Anti-DKK1 mAb (BHQ880) as a potential therapeutic agent for multiple myeloma. Blood (2009) 114(2):371-9. doi:10.1182/blood-2008-11-191577

113. Neri P, Tassone P, Shammas M, Yasui H, Schipani E, Batchu RB, et al. Biological pathways and in vivo antitumor activity induced by Atiprimod in myeloma. Leukemia (2007) 21(12):2519-26. doi:10.1038/sj.leu.2404912

114. Tassone P, Goldmacher VS, Neri P, Gozzini A, Shammas MA, Whiteman KR, et al. Cytotoxic activity of the maytansinoid immunoconjugate B-B4DM1 against CD138+ multiple myeloma cells. Blood (2004) 104(12):3688-96. doi:10.1182/blood-2004-03-0963

115. Hideshima T, Neri P, Tassone P, Yasui H, Ishitsuka K, Raje N, et al. MLN120B, a novel IkappaB kinase beta inhibitor, blocks multiple myeloma cell growth in vitro and in vivo. Clin Cancer Res (2006) 12(19):5887-94. doi:10.1158/10780432.CCR-05-2501

116. Ditzel Santos D, Ho AW, Tournilhac O, Hatjiharissi E, Leleu X, Xu L, et al. Establishment of BCWM.1 cell line for Waldenstrom's macroglobulinemia with productive in vivo engraftment in SCID-hu mice. Exp Hematol (2007) 35(9):1366-75. doi:10.1016/j.exphem.2007.05.022

117. Calimeri T, Battista E, Conforti F, Neri P, Di Martino MT, Rossi M, et al. A unique three-dimensional SCID-polymeric scaffold (SCID-synth-hu) model for in vivo expansion of human primary multiple myeloma cells. Leukemia (2011) 25(4):707-11. doi:10.1038/leu.2010.300

118. Bryant C, Suen H, Brown R, Yang S, Favaloro J, Aklilu E, et al. Long-term survival in multiple myeloma is associated with a distinct immunological profile, which includes proliferative cytotoxic T-cell clones and a favourable Treg/Th17 balance. Blood Cancer J (2013) 3:e148. doi:10.1038/bcj.2013.34

119. Feng P, Yan R, Dai X, Xie X, Wen H, Yang S. The alteration and clinical significance of Th1/Th2/Th17/Treg cells in patients with multiple myeloma. Inflammation (2014). doi:10.1007/s10753-014-9980-4

120. Birmann BM, Giovannucci EL, Rosner BA, Colditz GA. Regular aspirin use and risk of multiple myeloma: a prospective analysis in the health professionals follow-up study and nurses' health study. Cancer Prev Res (2014) 7(1):33-41. doi:10.1158/1940-6207.CAPR-13-0224

121. Prabhala RH, Pelluru D, Fulciniti M, Prabhala HK, Nanjappa P, Song W, et al. Elevated IL-17 produced by TH17 cells promotes myeloma cell growth and inhibits immune function in multiple myeloma. Blood (2010) 115(26):5385-92. doi:10.1182/blood-2009-10-246660

122. Noonan K, Marchionni L, Anderson J, Pardoll D, Roodman GD, Borrello I. A novel role of IL-17-producing lymphocytes in mediating lytic bone disease in multiple myeloma. Blood (2010) 116(18):3554-63. doi:10.1182/blood-201005-283895

123. Zheng MM, Zhang Z, Bemis K, Belch AR, Pilarski LM, Shively JE, et al. The systemic cytokine environment is permanently altered in multiple myeloma. PLoS One (2013) 8(3):e58504. doi:10.1371/journal.pone.0058504

124. Wesolowski R, Markowitz J, Carson WE III. Myeloid derived suppressor cells - a new therapeutic target in the treatment of cancer. J Immunother Cancer (2013) 1:10. doi:10.1186/2051-1426-1-10

125. Neri P, Tagliaferri P, Di Martino MT, Calimeri T, Amodio N, Bulotta A, et al. In vivo anti-myeloma activity and modulation of gene expression profile induced by valproic acid, a histone deacetylase inhibitor. Br J Haematol (2008) 143(4):520-31. doi:10.1111/j.1365-2141.2008.07387.x

126. Cea M, Cagnetta A, Gobbi M, Patrone F, Richardson PG, Hideshima T, et al. New insights into the treatment of multiple myeloma with histone deacetylase inhibitors. Curr Pharm Des (2013) 19(4):734-44. doi:10.2174/ 1381612811306040734

127. Adcock IM. HDAC inhibitors as anti-inflammatory agents. Br J Pharmacol (2007) 150(7):829-31. doi:10.1038/si.bjp.0707166

128. Youn JI, Kumar V, Collazo M, Nefedova Y, Condamine T, Cheng P, et al. Epigenetic silencing of retinoblastoma gene regulates pathologic differentiation 
of myeloid cells in cancer. Nat Immunol (2013) 14(3):211-20. doi:10.1038/ni. 2526

129. Nefedova Y, Fishman M, Sherman S, Wang X, Beg AA, Gabrilovich DI. Mechanism of all-trans retinoic acid effect on tumor-associated myeloid-derived suppressor cells. Cancer Res (2007) 67(22):11021-8. doi:10.1158/0008-5472. CAN-07-2593

130. Kusmartsev S, Cheng F, Yu B, Nefedova Y, Sotomayor E, Lush R, et al. All-transretinoic acid eliminates immature myeloid cells from tumor-bearing mice and improves the effect of vaccination. Cancer Res (2003) 63(15):4441-9.

131. Iclozan C, Antonia S, Chiappori A, Chen DT, Gabrilovich D. Therapeutic regulation of myeloid-derived suppressor cells and immune response to cancer vaccine in patients with extensive stage small cell lung cancer. Cancer Immunol Immunother (2013) 62(5):909-18. doi:10.1007/s00262-013-1396-8

132. Lust JA, Lacy MQ, Zeldenrust SR, Dispenzieri A, Gertz MA, Witzig TE, et al. Induction of a chronic disease state in patients with smoldering or indolent multiple myeloma by targeting interleukin $1\{$ beta\}-induced interleukin 6 production and the myeloma proliferative component. Mayo Clin Proc (2009) 84(2):114-22. doi:10.4065/84.2.114

133. Gabrilovich DI, Nagaraj S. Myeloid-derived suppressor cells as regulators of the immune system. Nat Rev Immunol (2009) 9(3):162-74. doi:10.1038/nri2506

134. Fricke I, Mirza N, Dupont J, Lockhart C, Jackson A, Lee JH, et al. Vascular endothelial growth factor-trap overcomes defects in dendritic cell differentiation but does not improve antigen-specific immune responses. Clin Cancer Res (2007) 13(16):4840-8. doi:10.1158/1078-0432.CCR-07-0409

135. Rodriguez PC, Ernstoff MS, Hernandez C, Atkins M, Zabaleta J, Sierra R, et al. Arginase I-producing myeloid-derived suppressor cells in renal cell carcinoma are a subpopulation of activated granulocytes. Cancer Res (2009) 69(4):1553-60. doi:10.1158/0008-5472.CAN-08-1921

136. Shojaei F, Wu X, Malik AK, Zhong C, Baldwin ME, Schanz S, et al. Tumor refractoriness to anti-VEGF treatment is mediated by CD11b+Gr1+ myeloid cells. Nat Biotechnol (2007) 25(8):911-20. doi:10.1038/nbt1323

137. Dirican A, Varol U, Kucukzeybek Y, Alacacioglu A, Erten C, Somali I, et al. Treatment of metastatic colorectal cancer with or without bevacizumab: can the neutrophil/lymphocyte ratio predict the efficiency of bevacizumab? Asian Pac J Cancer Prev (2014) 15(12):4781-6. doi:10.7314/APJCP.2014.15.12. 4781

138. Catlett-Falcone R, Landowski TH, Oshiro MM, Turkson J, Levitzki A, Savino R, et al. Constitutive activation of Stat3 signaling confers resistance to apoptosis in human U266 myeloma cells. Immunity (1999) 10(1):105-15. doi:10.1016/ S1074-7613(00)80011-4

139. Sansone P, Bromberg J. Targeting the interleukin-6/Jak/stat pathway in human malignancies. J Clin Oncol (2012) 30(9):1005-14. doi:10.1200/JCO. 2010.31.8907

140. Shojaei F, Wu X, Qu X, Kowanetz M, Yu L, Tan M, et al. G-CSF-initiated myeloid cell mobilization and angiogenesis mediate tumor refractoriness to anti-VEGF therapy in mouse models. Proc Natl Acad Sci U S A (2009) 106(16):6742-7. doi:10.1073/pnas.0902280106

141. Kowanetz M, Wu X, Lee J, Tan M, Hagenbeek T, Qu X, et al. Granulocytecolony stimulating factor promotes lung metastasis through mobilization of Ly6G+Ly6C+ granulocytes. Proc Natl Acad Sci U S A (2010) 107(50):21248-55. doi:10.1073/pnas. 1015855107

142. Waight JD, Hu Q, Miller A, Liu S, Abrams SI. Tumor-derived G-CSF facilitates neoplastic growth through a granulocytic myeloid-derived suppressor celldependent mechanism. PLoS One (2011) 6(11):e27690. doi:10.1371/journal. pone. 0027690

143. Bendall LJ, Bradstock KF. G-CSF: From granulopoietic stimulant to bone marrow stem cell mobilizing agent. Cytokine Growth Factor Rev (2014) 25(4):355-67. doi:10.1016/j.cytogfr.2014.07.011

144. Rapoport AP, Aqui NA, Stadtmauer EA, Vogl DT, Xu YY, Kalos M, et al. Combination immunotherapy after ASCT for multiple myeloma using MAGEA3/Poly-ICLC immunizations followed by adoptive transfer of vaccine-primed and costimulated autologous T cells. Clin Cancer Res (2014) 20(5):1355-65. doi:10.1158/1078-0432.CCR-13-2817

145. Sevko A, Umansky V. Myeloid-derived suppressor cells interact with tumors in terms of myelopoiesis, tumorigenesis and immunosuppression: thick as thieves. J Cancer (2013) 4(1):3-11. doi:10.7150/jca.5047

146. Ribechini E, Greifenberg V, Sandwick S, Lutz MB. Subsets, expansion and activation of myeloid-derived suppressor cells. Med Microbiol Immunol (2010) 199(3):273-81. doi:10.1007/s00430-010-0151-4
147. Botta C, Bestoso E, Apollinari S, Cusi MG, Pastina P, Abbruzzese A, et al. Immune-modulating effects of the newest cetuximab-based chemoimmunotherapy regimen in advanced colorectal cancer patients. J Immunother (2012) 35(5):440-7. doi:10.1097/CJI.0b013e31825943aa

148. Correale P, Botta C, Cusi MG, Del Vecchio MT, De Santi MM, Gori Savellini G, et al. Cetuximab \pm chemotherapy enhances dendritic cell-mediated phagocytosis of colon cancer cells and ignites a highly efficient colon cancer antigenspecific cytotoxic T-cell response in vitro. Int J Cancer (2012) 130(7):1577-89. doi:10.1002/ijc.26181

149. Noonan KA, Ghosh N, Rudraraju L, Bui M, Borrello I. Targeting immune suppression with PDE5 inhibition in end-stage multiple myeloma. Cancer Immunol Res (2014) 2(8):725-31. doi:10.1158/2326-6066.CIR-13-0213

150. Di Martino MT, Arbitrio M, Guzzi PH, Leone E, Baudi F, Piro E, et al. A peroxisome proliferator-activated receptor gamma (PPARG) polymorphism is associated with zoledronic acid-related osteonecrosis of the jaw in multiple myeloma patients: analysis by DMET microarray profiling. Br J Haematol (2011) 154(4):529-33. doi:10.1111/j.1365-2141.2011.08622.x

151. Marra M, Salzano G, Leonetti C, Tassone P, Scarsella M, Zappavigna S, et al. Nanotechnologies to use bisphosphonates as potent anticancer agents: the effects of zoledronic acid encapsulated into liposomes. Nanomedicine (2011) 7(6):955-64. doi:10.1016/j.nano.2011.03.004

152. Marra M, Abbruzzese A, Addeo R, Del Prete S, Tassone P, Tonini G, et al. Cutting the limits of aminobisphosphonates: new strategies for the potentiation of their anti-tumour effects. Curr Cancer Drug Targets (2009) 9(7):791-800. doi: $10.2174 / 156800909789760285$

153. Caraglia M, D’Alessandro AM, Marra M, Giuberti G, Vitale G, Viscomi C, et al. The farnesyl transferase inhibitor R115777 (Zarnestra) synergistically enhances growth inhibition and apoptosis induced on epidermoid cancer cells by Zoledronic acid (Zometa) and Pamidronate. Oncogene (2004) 23(41):6900-13. doi:10.1038/sj.onc. 1207814

154. Tassone P, Tagliaferri P, Viscomi C, Palmieri C, Caraglia M, D’Alessandro $\mathrm{A}$, et al. Zoledronic acid induces antiproliferative and apoptotic effects in human pancreatic cancer cells in vitro. Br J Cancer (2003) 88(12):1971-8. doi:10.1038/sj.bjc.6600986

155. Tassone P, Galea E, Forciniti S, Tagliaferri P, Venuta S. The IL-6 receptor superantagonist Sant7 enhances antiproliferative and apoptotic effects induced by dexamethasone and zoledronic acid on multiple myeloma cells. Int J Oncol (2002) 21(4):867-73.

156. Tassone P, Forciniti S, Galea E, Morrone G, Turco MC, Martinelli V, et al. Growth inhibition and synergistic induction of apoptosis by zoledronate and dexamethasone in human myeloma cell lines. Leukemia (2000) 14(5):841-4. doi:10.1038/sj.leu.2401770

157. Dieli F, Gebbia N, Poccia F, Caccamo N, Montesano C, Fulfaro F, et al. Induction of gammadelta T-lymphocyte effector functions by bisphosphonate zoledronic acid in cancer patients in vivo. Blood (2003) 102(6):2310-1. doi:10.1182/blood-2003-05-1655

158. Melani C, Sangaletti S, Barazzetta FM, Werb Z, Colombo MP. Aminobiphosphonate-mediated MMP-9 inhibition breaks the tumor-bone marrow axis responsible for myeloid-derived suppressor cell expansion and macrophage infiltration in tumor stroma. Cancer Res (2007) 67(23):11438-46. doi:10.1158/0008-5472.CAN-07-1882

159. Heissig B, Hattori K, Dias S, Friedrich M, Ferris B, Hackett NR, et al. Recruitment of stem and progenitor cells from the bone marrow niche requires MMP-9 mediated release of kit-ligand. Cell (2002) 109(5):625-37. doi:10.1016/S0092-8674(02)00754-7

160. Porembka MR, Mitchem JB, Belt BA, Hsieh CS, Lee HM, Herndon J, et al. Pancreatic adenocarcinoma induces bone marrow mobilization of myeloidderived suppressor cells which promote primary tumor growth. Cancer Immunol Immunother (2012) 61(9):1373-85. doi:10.1007/s00262-011-1178-0

161. Alizadeh D, Katsanis E, Larmonier N. Chemotherapeutic targeting of myeloidderived suppressor cells. Oncoimmunology (2014) 3(1):e27359. doi:10.4161/ onci.27359

162. Roth F, De La Fuente AC, Vella JL, Zoso A, Inverardi L, Serafini P. Aptamermediated blockade of IL4Ralpha triggers apoptosis of MDSCs and limits tumor progression. Cancer Res (2012) 72(6):1373-83. doi:10.1158/0008-5472.CAN11-2772

163. Qin H, Lerman B, Sakamaki I, Wei G, Cha SC, Rao SS, et al. Generation of a new therapeutic peptide that depletes myeloid-derived suppressor cells in tumor-bearing mice. Nat Med (2014) 20(6):676-81. doi:10.1038/nm.3560 
164. Soon P, Kiaris H. MicroRNAs in the tumour microenvironment: big role for small players. Endocr Relat Cancer (2013) 20(5):R257-67. doi:10.1530/ERC13-0119

165. Li X, Wu Z, Fu X, Han W. A microRNA component of the neoplastic microenvironment: microregulators with far-reaching impact. Biomed Res Int (2013) 2013:762183. doi: $10.1155 / 2013 / 762183$

166. Heimberger AB, Gilbert M, Rao G, Wei J. MicroRNAs as novel immunotherapeutics. Oncoimmunology (2013) 2(8):e25124. doi:10.4161/onci.25124

167. Yu HW, Sze DM, Cho WC. MicroRNAs involved in anti-tumour immunity. Int J Mol Sci (2013) 14(3):5587-607. doi:10.3390/ijms14035587

Conflict of Interest Statement: The authors declare that the research was conducted in the absence of any commercial or financial relationships that could be construed as a potential conflict of interest.
Received: 13 October 2014; paper pending published: 16 November 2014; accepted: 23 November 2014; published online: 08 December 2014.

Citation: Botta C, Gullà A, Correale P, Tagliaferri P and Tassone P (2014) Myeloidderived suppressor cells in multiple myeloma: pre-clinical research and translational opportunities. Front. Oncol. 4:348. doi: 10.3389/fonc.2014.00348

This article was submitted to Hematology Oncology, a section of the journal Frontiers in Oncology.

Copyright (C) 2014 Botta, Gullà, Correale, Tagliaferri and Tassone. This is an openaccess article distributed under the terms of the Creative Commons Attribution License (CC BY). The use, distribution or reproduction in other forums is permitted, provided the original author(s) or licensor are credited and that the original publication in this journal is cited, in accordance with accepted academic practice. No use, distribution or reproduction is permitted which does not comply with these terms. 